\title{
Political Ethics by Sheikh Hasina And Khaleda Zia's Government from 2009 to Present: A Research on Literature Review
}

\author{
Mohammad Eisa Ruhullah ${ }^{*}$, Zuly Qodir ${ }^{2}$ \\ ${ }^{1}$ The Prime Minister's Office, Dhaka Government of the People's Republic of Bangladesh. \\ 1,2 Master of the Government Affairs and Administration, Jusuf Kalla School of Government, \\ University of Muhammadiyah Yogyakarta, Indonesia \\ ${ }^{*}$ Corresponding Author Email: eisa.iium@gmail.com
}

\begin{abstract}
The principal motive of this research is to analyze the status of ethical, democratic government and Public Services in Bangladesh. This paper examines the state of democratic governance in various rulers of Bangladesh, especially during Sheikh Hasina and Khaleda Zia's governmental from 2009 to present. With qualitavie method This paper begins with a conceptual analysis of democratic governance and then identifies several vital problems. This article explains the status of ethical, democratic public services in Bangladesh in terms of some critical elements/elements of democratic governance, including the development of democratic institutions. Furthermore, processes, strengthening electoral and law enforcement systems, improving access to justice through freedom to the division of power, and encouraging citizen participation. Answer promoting tolerance, transparency, promoting democratic values and respect of liberty in public services with good governance and ethics, which are very infrequent in current Bangladesh politics.
\end{abstract}

Keywords: Ethical- Politics; Public-Service;, Political habit- in Bangladesh, Dominant-favoritism.

\begin{abstract}
Abstrak
Motif utama dari penelitian ini adalah untuk menganalisis status pemerintahan yang etis, demokratis dan Pelayanan Publik di Bangladesh. Makalah ini mengkaji keadaan pemerintahan demokratis di berbagai penguasa Bangladesh, terutama selama periode pemerintahan Sheikh Hasina dan Khaleda Zia dari tahun 2009 hingga sekarang. Dengan Metode kualitatif Makalah ini dimulai dengan analisis konseptual dari pemerintahan demokratis dan kemudian mengidentifikasi beberapa masalah penting. Artikel ini menjelaskan status layanan publik yang etis dan demokratis di Bangladesh dalam kaitannya dengan beberapa elemen penting / elemen pemerintahan demokratis, termasuk pengembangan lembaga demokrasi. Selanjutnya, proses, penguatan sistem pemilu dan penegakan hukum, peningkatan akses keadilan melalui kebebasan pembagian kekuasaan, dan mendorong partisipasi warga. Menjawab mempromosikan toleransi, transparansi, mempromosikan nilai-nilai demokrasi, dan menghormati kebebasan dalam layanan publik dengan tata kelola dan etika yang baik, yang sangat jarang terjadi dalam politik Bangladesh saat ini.
\end{abstract}

Kata kunci: Etis- Politik; Pelayanan publik, Kebiasaan politik- di Bangladesh, Favoritisme yang dominan

\section{INTRODUCTION}

The public sector is crucial for a government to establish their good governance in the state by practicing the freedom of public services. In a democracy, people are considered as the source of all energy. They hope that the government will meet all their needs and needs through companies or agencies (Lewis,

* Copyright (c) 2020 Mohammad Eisa Ruhullah, Zuly Qodir

This work is licensed under a Creative Commons Attribution-ShareAlike 4.0 International License.

Received: October 1, 2020; Revised: November 7, 2020; Accepted: November 9, 2020 
Khazanah Sosial, Vol. 2 No. 3: 166-178

Political Ethics by Sheikh Hasina And Khaleda Zia's Government from 2009 to Present: A Research on Literature Review

Mohammad Eisa Ruhullah, Zuly Qodir

2017). They also hope that the government will prove its constitutional obligations are not only in the public interest but also in the hands of the people. The exercise of this power for the people is subject to the authority of the Constitution and will only be practical. This study is focusing on the public policy and practice in Bangladesh via content analysis of other research papers that studied on the ethical public administration by political leaders of Bangladesh (Alam, 2017). The first question of this research paper is why the public sectors are not free mood in Bangladesh?

By contrast, Bangladesh's most of the public sectors facing the dominant forces from the higher authority such as political pressure. In an undemocratic society, power originates from the ruler, not from the people. The question of accountability for his actions does not arise; as a result, the regime becomes authoritarian. Authoritarianism is about to end democratic practices, including the rule of law, electoral choice, the political bargaining, free speech and free speech of political demand (TALIB A. YOUNISIQBAL M.D. MOSTAFA, 2018). The second research question is, what are the reasons for the failure of governance in Bangladesh till today? This study will make a comparison analytical review of the tow government rulers of Bangladesh from 2000 to the present Khaleda Zia and Sheikh Hasina. This paper will try to find out the solution to this problem that mentioned above regarding the implication of the freedom of Public services with ethically and democratically in Bangladesh.

In addition, polls in Bangladesh are conducted and administered by an autonomous body known as the Election Commission (EC), which is constitutionally authorized and empowered. Legally, the EC must maintain neutrality in its election-related responsibilities, for or against the ruling or opposition parties (Shukla, 2018). However, since 1991, the EC has become a highly political and controversial institution. Since it has absolute power in determining district boundaries, nominating, and electing, distributing ballot boxes, and counting votes, the ruling parties tend to use conventional institutions in their favour by appointing gay or biased commissioners. Opposition parties, aware of this fact, have taken it seriously in the mid-1990s and late 1990s, leading to severe opposition government movements and national political crises (M. A. Islam et al., 2017).

Thus, the appointment of an Election Commissioner is an essential consideration of a present government. Over the past decade, this has become a norm in favour of government elections, as voices and influence of opposition parties wholly diminished through an autocratic elected government. Since 1995 , the seven chief election commissioners have been considered highly controversial and highly biased because their decisions and actions supported the government's priorities. The most infamous Chief EC was the 11th Commissioner (2012-2017) when the 2014 National and 201 Union Councils elections were the most controversial and disastrous for the ruling party(Moniruzzaman M, 2016).

As for previous research on the government of Sheikh Hasina and Khaleda Zia's as in Mohiuddin (2008) which discusses the military side of the government of Sheikh Hasina and Khaleda Zia's, Khondker (2017) on Politics, personality and policies Sheikh Hasina and Chakma (Chakma, 2015) which discusses Analyze the sources of the Sheikh Hasina government's India-positive foreign policy approach from theoretical and empirical standpoints. From several previous studies, there is still no one that really focuses research on Political Ethics by Sheikh Hasina And Khaleda Zia's Government.

In short, we need educated expert administrators and a team of intense political and ethical leaders committed to preventing corruption, accountability, transparency, and inefficiency. Enforcing the rule of law on a strong ethical basis is essential to ensure good governance and sustainable development. The results of the research will help the political parties, administrators, the public, students, researchers, political leaders and policymakers design future sustainable improvement policies and projects based on good governance and ethics. 
Khazanah Sosial, Vol. 2 No. 3: 166-178

Political Ethics by Sheikh Hasina And Khaleda Zia's Government from 2009 to Present: A Research on Literature Review

Mohammad Eisa Ruhullah, Zuly Qodir

\section{RESEARCH METHOD}

In order to explore the study objectives, historical approaches to the research method have been adopted. In this case, the historical developmental development and critical evaluation of the subject have been considered to compare with the existing situation. All data have been collected from books, journals, articles, newspapers, and websites depending on the nature of the research in the same development (Hasina \& Hasan, 2015a). The previous studies on practices of political ethics and governance of Bangladesh current and previous government such as Sheikh Hasina and Khaleda Zia. It will be the focus of the paper that Further critique and review objectively published or printed information, the content analysis methodology was applied with qualitative approach.

\section{RESULTS AND DISCUSSION}

\section{Definition of a Good and Ethical Government}

Public sectors are the government bodies to serve the country under their responsibilities. It is to make sure that public services are reaching out to every citizen in the states that is the excellent and ethical government. Public service is a service that is provided directly to people living within the jurisdiction (through the public sector) or through the financing of service. The term is associate with a social sensation (usually expressed through democratic elections) that certain services whatever the income, it should be available to everyone (Ranerup \& Henriksen, 2019). A public service belongs to the government, and administrative agencies give to the people of the area and are considered essential to modern life. Ghartey confides that liability provides multiple checks and counterchecks in the political and decision-making process. Effective indebtedness for him is better understood in the context of efficiency. He also sees accountability in terms of expenditure, dedication, loyalty, and high moral/ethical standards, arguing that effective accountability provides the public with access to government knowledge (TALIB A. YOUNISIQBAL M.D. MOSTAFA, 2018).

\section{Sheikh Hasina and Khaleda Zia's Practices of Ethical Politics in the Country}

This Grand Alliance set the government on 6 January 2009 among Sheikh Hasina, repeated as the prime minister. People keep high expectations that the administration will initiate significant reforms to develop undemocratic political methods. That was hoped that the two political authorities would learn from their earlier errors, resolve their disputes over democratic dialogue and discussion, plus not resort to road politics also violence. However, regrettably, after the election, both sides decided to continue their old political dispute path. For example, the BNP started striking parliamentary sittings and called for road agitations. Opposite to its pre-election commitment of building consent, the ruling coalition used its threefourth preponderance in parliament to push through the fifteenth amendment of the constitution in June 2011, which interjected numerous changes exposed by the BNP-led coalition. The prime and most critical of the reforms, defended by BNP, was the cancellation of the nonpolitical caretaker government NCG's provision for organizing future governmental elections. Then the BNP denied participating in the parliamentary polls under a party convention (BAL) (Jahan, 2014).

Therefore, Bangladesh's public administration still faces corruption, violence, lack of the rule of law, old laws, transparency, lack of professionalism, human rights abuses, accountability, and even severe politicization of government institutions and even the judiciary (Sarker et al., 2017). For the past decade, the disappearance, imprisonment, abuse, and custody of slanderers of Sheikh Hasina's administration has 
Khazanah Sosial, Vol. 2 No. 3: 166-178

Political Ethics by Sheikh Hasina And Khaleda Zia's Government from 2009 to Present: A Research on Literature Review

Mohammad Eisa Ruhullah, Zuly Qodir

been an open secret in Bangladesh. Within the electoral leadership, efforts to silence critical opinion have risen to the top. As Sheikh Hasina begins her last term, she cruises the country in response to a slippery slope of authoritarianism. Politically, there is a vulnerability that once her ruling Awami League becomes too involved in the power policy, the peaceful transference of power to another party. It will become more difficult. By enabling the government to pursue and imprison its critics in light of the new 2018 Digital Security Act, growing restrictions on freedom of expression will only increase resentment and possibly lead to disorder (Salomon Heiner, Wake Caitlin, Jones Nicola, 2019).

Furthermore, Security crisis is one of the biggest issues in most of the government duration in Bangladesh due to political and non-political relationship. It causes a lot of families lost their beloved one and even in some cases the family have not find the death body of them disappear family members. But this is happening in every governmental term the social security crisis. For example, during the former prime minister Khaleda Zia's time there were so many opposition leaders were disappeared those are from the current government of Bangladesh political leaders such as the news reported in Timesnownews.com where current prime minister claimed that 21st August attached on Awami League arranged by the son of former prime minister Khaleda Zia (timesnownews.com, 2018). In return, now the BNP leaders are facing the same problems as they said in some news such as CNN and BBC broadcast (Anbarasan, 2012). According to Bangladesh national news paper's report of disappearance of 1209 people were force to disappeared by the ruling government of Bangladesh (Prothom Alo, 2019).

This study reached to a conclusion of public sectors' services condition and practices by the previous prime minister of Bangladesh namely Khaleda Zia and current prime minister Sheikh Hasina. Bangladesh is a highest population country in the world with small land compare to its citizens (Ali, 2015). There are few cities that can be discuss on this study regarding the public services. For example, People in Chittagong City are often dissatisfied with the quality of services provided by various city authorities (during Khaleda Zia's Government) and the acute water and electricity crisis, sanitation problems, waste management of waste drainage, lack of treatment and healthcare facilities, and infrastructural insufficiency of roads and sewer (Lewis, 2017). In another article included the former prime minister of Bangladesh namely Khaleda Zia as a corrupted leader (Kabir \& Parolin, 2012). The literature review shows that current prime minister of Bangladesh (Sheikh Hasina's government) is concerning about fulfilling the public services in responsibly, which is better than all other previous government (Karim, 2015).

Moreover, Substantial political institutions were/are engaged in political party quarrels. The seizure of government power by a political party prevents diversity in critical political institutions. Notable is the Election Commission which has become an essential focal point of political conflict. After independence, the entire government failed to form an independent election commission and separate it from the Prime Minister's Office. Those in power at the government and their appointees have always appointed 'friends' to do their hidden agendas such as to the Election Commission to demand their removal from the opposition (M. A. Islam et al., 2017). For example, Prime Minister Sheikh Hasina Wazed's government elected made a firm commitment in 2010 to address serious human rights issues. However, that promise has not been fulfilled, as extrajudicial executions and torture continues, as well as impunity for members of the security forces. The government continued to attack the media and the right to express the views of political opponents. Workers' union workers protesting for higher wages were systematically targeted and, in some cases, arrested and imprisoned on Trump-up charges (UK Border Agency, 2011). 
Khazanah Sosial, Vol. 2 No. 3: 166-178

Political Ethics by Sheikh Hasina And Khaleda Zia's Government from 2009 to Present: A Research on Literature Review

Mohammad Eisa Ruhullah, Zuly Qodir

\section{The Backdrop of Two Political Leaders in Bangladesh; Sheikh Hasina and Khaleda Zia}

Since independence in 1971, Bangladesh has faced several political challenges. After the restoration of democracy in the nineties, power reigned between Khaleda Zia and Sheikh Hasina. The country is plagued by local corruption. Although anti-corruption laws exist, they are not adequately enforced, and relevant institutions are not sufficient. Contortion in Bangladesh obstructs proper allocation of assets, weakens government services, reduces fertility, exacerbates poverty, marginalizes the poor and creates social unrest. Bangladeshi poor are equally deprived of education and white-collar jobs. Irregularities in recruitment were visible, and in many cases, corruption has a built-in bias against the poor, disadvantaged and low-income segments of society (Kaunain Rahman, 2019).

Sheikh Hasina's Regime (1996-2001); The Awami League came to power in 1996 through the 7th elections. First, the government set up a commission to restructure the local government level. The commission proposed to establish at the village level along other levels of local government. As per the proposal of the commission, the government introduced the Gram Parishad Act 1997 under which village government would be established based on wards. The elected chairman of the Union Parishad will be the ex-officio chairman of the Gram Parishad. The village council will have three members including two women members. Government officials were also given the opportunity to become members of the council. Although the law establishing the village council was enacted, no steps were taken to form it (Hasina \& Hasan, 2015a).

Moreover, Khaleda Zia's Rules (2001-2006); Khaleda Zia took charge of the government for the second time. During that period, the government repealed the Gram Parishad Act 1997 and enacted a new law in 2003 called the Village Government Act to establish village government on a ward basis. Although the previous government represented a local body of representative nature in ensuring the participation of the people in development activities in the enactment of the said Act, it also provided for nomination instead of election in the presence of village government formation (Nasrin, 2013). Sheikh Hasina's rules (2009 to present); However, this term many laws related to local government were passed during the tenure of this government such as Local Government (City Corporation) Act, 2009, Local Government (Municipal Corporation) Act, 2009, Union Parishad Act, 2009 (Ministry of Local Government), Bangladesh) . Upazila Parishad Act, 1998 has been restored. However, no steps have been taken to establish a village government (Hasina \& Hasan, 2015b).

At present, the current milieu in the densely populated country continues unabated as it goes through substantial economic and social changes. Following the boycott of the 2014 elections, the ruling Awami League's main opposition party, the Bangladesh Nationalist Party (BNP), led security forces to arrest and harass key party officials. Nonetheless, the regranting Awami League has integrated political forces through critical voices in the media and civil society, which are seen as anti-government and allied with them. Such steps have done much damage to the opposition BNP as well as the Jamaat-e-Islami (JI) (Kaunain Rahman, 2019). Furthermore, the prevailing party resorted to relentless measures such as cracked disappearances to eradicate democracy. Rizvi said the ruling party was using the use of invisibility as a weapon to stifle opposition and alternative views and to prolong its 'authoritarian one-party rule' (Zia, 2013). A total of 1,209 people has gone missing since the formation of the Awami League government in 2009. BNP senior joint secretary general Ruhul Kabir Rizvi said that 1 of them went missing by the law enforcement agencies (Prothom Alo, 2019).

Furthermore, This BAL-led Grand Alliance administration began performing the pledge of a trail of independence war criminals. The Jamaat Islam activists, especially members of this Islami Chhatra Shibir, 
Khazanah Sosial, Vol. 2 No. 3: 166-178

Political Ethics by Sheikh Hasina And Khaleda Zia's Government from 2009 to Present: A Research on Literature Review

Mohammad Eisa Ruhullah, Zuly Qodir

unleashed a stream of unprecedented road violence, including armed atrocities on law implementation agencies after those verdicts of the war crimes trials, started to be declared from early 2013. Attempts by the United Nations (UN) to convince the significant two political parties to come to a contracted settlement about an election-time government failed. Then BNP-led alliance ostracized and ventured to thwart the scheduled gubernatorial election with reinforcing oborodh (blockade) also hartals. This government countered by harsh effects, including returned and substantial scale arrest of BNP leaders. There were unprecedented violent disputes betwixt Jamaat activists and law enforcement auspices. Though, the administration was capable of organizing a one-sided parliamentary election ostracized by the BNP-led units. In a most maximum of the legislative seats (153), MPs referring to the BAL-led alliance were 'elected' uncontested. In the outstanding 147, contestations selected place with a meager voter output on 5 January 2014. That parliamentary opponent engineered among the Jatiya Party's schism, who decided to join both the government as ministers and serve as complaints in parliament. Then BAL-led alliance established the government on 12 January 2014 till the present (Jahan, 2018) and (Jahan, 2014).

\section{Leadership history of Sheikh Hasina and Khaleda Zia}

The study found that there was major different between leadership of Khaleda Zia and Sheikh Hasina's governance of public sectors services. The differences will be as follows with comparison discussion in this phase. Various scholars have explicitly argued that the bureaucracy's view is that politicians play an elite, defective role in Bangladesh governance. Elected leaders began to rely more on senior civil servants for advice on important issues. Government employees and government initiatives replaced the political appointments at the core of the secretariat, and they began to make most of the decisions. Political reasons, it really implies that since the time of Great Britain, Bangladesh has been setting this historical historically dominant mind because of the political pressure of the British regime since the British era, when they created all the political pressure on the government and nongovernmental organizations as a result of the change of political leadership. Bureaucratic half in the process deepens the core of consolidation and generates bureaucracy as one of the most influential actors in policy networks. To clarify, we must look back at the working relationship between politicians and civil servants in this country. Act 1919 during the colonial rule, under Indian law of British bureaucrats served under politicians (the first Indian ministers were appointed at the provincial level) (Huque \& Ferdous, 2019).

Furthermore, Sheikh Hasina and Khaleda Zia (two female leaders) made their debut in Bangladeshi politics due to the low level of political organization in the absence of suitable male heirs. All three sons of Sheikh Mujibur Rahman (Mujib) died; So, there was no male member left to lead the Awami League. In another camp, Ziaur Rahman's sons died at a young age, forcing Khaleda Zia to lead the Bangladesh Nationalist Party (BNP). Both Sheikh Hasina and Khaleda Zia played vital roles in the 1990 mass explosion versus General Ershad. Following 1991, the congressional election beneath a caretaker government, the BNP headed by Khaleda Zia formed the power and Sheikh Hasina, leader of the AL, enhanced the leader of the competition in the congress. In 1996, the AL obtained the election, and Sheikh Hasina became the Prime Minister. In 2001, national election, the BNP and its three alliance partners secured a two-thirds majority and Khaleda Zia again formed the power. In 2008, parliamentary election, Sheikh Hasina came to power with a landslide victory, and Khaleda Zia became the head of the opponent (Chowdhury, 2015).

However, the leadership of the Bangladesh government has not been on the line of democracy since 2000. With the shake of power, Bangladesh is fast becoming one of the most vibrant democracies in Asia towards a single-family. Six months before the election, Sheikh Hasina is trying to remove the need for a 
Khazanah Sosial, Vol. 2 No. 3: 166-178

Political Ethics by Sheikh Hasina And Khaleda Zia's Government from 2009 to Present: A Research on Literature Review

Mohammad Eisa Ruhullah, Zuly Qodir

caretaker government from the constitution. Herself helped establish the rule, which called for an apolitical government to seize power and observe the electoral process regardless of political interference. The caretaker government is that the elections have been relatively and reasonably insured. If voters decide to vote for the new government, power must change hands. Despite participating in millions of street protests against plans to overthrow the caretaker government ahead of this year's (2013) general election, she believes that he will give a chance to be re-elected despite opposition from the people.

In recent years, Bangladesh has reacted to authoritarian rule. The established political tradition of holding inclusive and peaceful elections under a non-partisan caretaker government was abolished in 2011 when the opposition boycotted the 2014 general election without contesting more than 50 parliamentary seats. Throughout the most current polls, government defense forces launched an unmerciful crackdown to protesters whose members also responded with violence. It was also claimed that the vote was rigged. An independent survey by Transparency International confirmed significant irregularities, including ballot stuffing, in 47 of the 50 sample seats. The reigning Awami League (AL) government has suffered little opposition in the Bangladeshi parliament and consolidated its power through violent repression. Political opponents have gone 'missing', and leaders of parties outside the ruling coalition have been imprisoned.

Furthermore, there are remarkable apparent consequences of this 'structural opponent culture' in Bangladesh. First, that undermines the peaceful rapprochement of cooperation amongst political parties because 'opposition' inhabits the main political program. Secondly, because opponents to rival political parties get the highest market money, the political leaders continue obsessed with finding new issues and different methods to attack their political rivals. That brings to politics the practices of misrepresentation, concoction, weirdness, active denial, fabrication, and new actualities. Through speeches at a political meeting, political leaders spend more time hitting political rivals than offering pragmatic agendas for the nation's advancement. These practices of lying and mixture enhance normalized. New sophisticated methods of concocting or manufacturing facts plus actualities to attack political opponents are always embraced and applauded in the domain of politics. Partisan rivalry and resentment sometimes strike to such an ultimate level that some political leaders mislay their last iota of allegiance also then discursively portray the state as 'fundamentalist' or a 'breeding earth of Talibanize' plus so forth to welcome foreign interference. Third, it produces fanaticism indoors politics.

Consequently, no art develops based on any prospective vision as leaders are troubled, including attacking others alternatively. That country's growth and progress shift secondary, plus the political realm does not recognize visionary, also honest leaders. This then creates a 'demo-crisis' in which this country is stripped of extensional and visionary rulers and conscientious citizens plus vibrant civil civilization.

\section{Practices of Ethics and Good Governance}

The researcher found that unethical and argumentative imprisonment of former Bangladeshi Prime Minister Khaleda Zia and the crackdown on state dissent have raised fears that the upcoming parliamentary elections could turn violently dirty. Fearing a repeat of 2014, when almost all opposition parties boycotted the parliamentary elections and witnessed widespread violence and killings, the ruling Awami League (AL) government in Bangladesh has faced allegations of organized torture by an opposition party. Opposition leaders and political activists are living in prison or under threat of aggravation, but there is widespread concern about what will happen in an election year. With the controversial imprisonment of Bangladesh's opposition leader and two-time prime minister Khaleda Zia last month, it is becoming 
Khazanah Sosial, Vol. 2 No. 3: 166-178

Political Ethics by Sheikh Hasina And Khaleda Zia's Government from 2009 to Present: A Research on Literature Review

Mohammad Eisa Ruhullah, Zuly Qodir

increasingly difficult for Prime Minister Sheikh Hasina's government to deny allegations of authoritarian rule (Mahmud, 2018).

Furthermore, elections are held in Bangladesh at seven levels of administration, both national and local. From top to bottom, these are presidential elections, national parliamentary elections, city corporation elections, district council elections, subdivision elections, municipal elections, and union council elections. Elections at all levels are conducted along party lines. In the first decade of independence, elections were, for the most part, a reasonably competitive game for representative politics. Either the people were not highly socialized politically, or the field of political participation was not limited to the townspeople, the elections were systematic, there was competition among professional politicians, and there was the representation of qualified politicians. Over time, nevertheless, representative politics became tainted by money, muscle, violence, manipulation, and indeed became commercially commercial. The intents of such stigmatized representative politics were twofold: to keep the ruling party in power by any means and to prevent the opposition from coming to power by any means. Within these two purposes, the real goal of political representation through elections faded. It has continued the politics of resistance representation and the regularization of dictatorial democracy in Bangladesh.

However, there has been a crisis in the ethical practice of leadership. In early 2018, for example, the Leader of the Opposition (former Prime Minister Khaleda Zia) was sentenced to seven years in prison on corruption charges that some claims were politically motivated. Nonviolent protests by students demanding road safety rules and fair access to government jobs have been violently suppressed, and journalists and photographers have been attacked by police forces covering events (Antonio Savoia, 2019). Moreover, in Bangladesh the law and court also dominated by its governmental system because they are the one who appointed the judge at all level of the court in the country. That is why there is always some interruption in the court during the justice. And this can create all the distrust and disobey people in the state towards the highest court as well due to lack of justice. Freedom in the public service sectors is very necessary to practice the fully duty of servant. As a public servant they need free space to do their job properly when its needed. Bangladesh has some key elements/components of democratic governance, including developing democratic institutions and processes, strengthening electoral and law enforcement systems, improving access to justice by ensuring segregation of powers, citizen participation, accountability, transparency, promoting democratic values, human rights and respect.

Furthermore, in a democratic method, this is vital to have contentious and sophisticated party conformity. Nevertheless, Bangladesh has encountered a dogmatic also a confrontational party policy that has built a deadlock and caused ambiguity to the whole country. Considering 1990, except 2014 and 2018, Bangladesh has testified four systematic well-disposed, free votes, for example, in 1991, 1996, 2001, plus 2008. On January 5, 2014, and 2018, nonetheless, dubious elections took place where significant opponent political parties did not engage except the ruling coalition parties. These two prevailing parties; the Bangladesh Nationalist Party (BNP) plus the Bangladesh Awami League (BAL)—each obtained two prior free and fair polls, with the BNP gaining in 1991, also a BNP-led 4-party combination in 2001, including the BAL in 1996, plus a BAL-led 14 party affiliation in 2008. Nevertheless, from 2014 Bangladesh is directing towards a dictatorial system. Total these are occurring due to the absence of good governance (S. S. Islam, 2016) and (M. N. Islam et al., 2020).

Moreover, At the end of the BNP-led 4-party coalition regime (2001-2006), the BAL-led 14-party alliance removed the probability of determining their issues plus concerns in the parliament about the configuration of a caretaker government and impending elections. Both parties took demands on streets, including the ruling coalition, and admitted to a dialogue with the BAL on those matters outside the 
Khazanah Sosial, Vol. 2 No. 3: 166-178

Political Ethics by Sheikh Hasina And Khaleda Zia's Government from 2009 to Present: A Research on Literature Review

Mohammad Eisa Ruhullah, Zuly Qodir

parliament's domain. Nevertheless, the BAL denied sitting with the BNP-ruling coalition parties, notably with the Jamat-e-Islami Bangladesh (JIB). However, the BAL plus other leaders of the 14-party coalition had sat among the JIB leaders on many events in the past. This BNP-ruling coalition responded among almost the equal magnitude of obduracy that it would not enroll in a dialogue among the BAL outwardly its coalition companion the JIB. All those improvements only bothered the crises besides.

Finally, 'the fundamental of opponent' culture produces hatred, separation, mistrust, anxiety, and endless political tension. Seldom is political tension turned into violence and murder, and 'corpse politics' appears. If any political activist is hit or aggravated due to political brutality, this is not commonly observed as a political failure; instead, that 'corpse' becomes political property to generate a current issue in the refined atmosphere of political opposition. It is an unhealthy 'structural opposition' culture that has remained for decades. A healthful political environment among viable democratic practices has not grown; therefore, it prevails retrogressive. That has paved the way for foreign diplomats to interfere in the country's interior affairs, such as what occurred in 2006 BNP and 2014- 2018 BAL. Administering with some evil political leaders may rock, merely will not root out, that long-established framework of architectural opposition growing.

\section{Suggestion}

From the research discussion, good governance is essential for sustainable development in all areas of a country. However, the status of public administration in Bangladesh is not satisfactory. It is better to adopt some strategies such as recruitment system should be free from illegal political barriers, no politicization should be allowed, corruption Eliminate, improve policy implementation capacity, promote local administration, and give justice to the rural poor. Ensuring partnership and access, improving sectoral government, improving sustainable and efficient governance, and more effective measures should take, such as strengthening robust and institutional capacity through strong parliament and strong leadership and strengthening parliamentary oversight. The public administration is an ecology of closely related to the approach to sustainable development which in a country like Bangladesh should address the dependence, balance, biological system, and sustainability of human life with ethics.

\section{CONCLUSION}

Answering to the first research question, every government follow their own systems to fulfill their vision and mission. In the case of Bangladesh government from its independent till now there was so many leaders came via election and no election such as military leaders and elected government from two major parties such as Awami League and Bangladesh National Party (BNP) (Kaunain Rahman, 2019). The political policy of unstable Bangladesh lacked mutual trust and consideration. All political parties have resorted to any means to seize power. More than 80 parties were agitated in the political arena, but only two dominated: the Awami League and the Bangladesh Nationalist Party. The Bangladesh Awami League was one of the largest and was initially established as the Pakistan Awami Muslim League. After independence, Sheikh Mujibur Rahman controlled the party and renamed it Bangladesh Awami League. The party has ruled four times since its release and is currently the ruling party. The Bangladesh jatiyotabadi Party, another major political party, was founded by President Ziaur Rahman on September 1st, 1978 and has ruled Bangladesh for three terms since its birth (M. A. Islam et al., 2017). Furthermore, this paper found that the democratic governance of Bangladesh was hampered by various reasons such as lack of authority by the government, lack of political commitment and sensibility, absence of independent 
Khazanah Sosial, Vol. 2 No. 3: 166-178

Political Ethics by Sheikh Hasina And Khaleda Zia's Government from 2009 to Present: A Research on Literature Review

Mohammad Eisa Ruhullah, Zuly Qodir

judiciary, lack of accountability of elected and appointed government. Officials, lack of democratic practice among political parties, participation, or engagement of citizens in the political process and rampant corruption (Hasan Mubashar, 2019).

Besides, Sheikh Hasina has been in power since 2009; therefore, it is conjectured that she will not be able to hold fair elections. It must always be managed to ensure his victory. The removal of the CTG was not tricky, despite strong rejections from opposition parties and the public, as Parliament and the judiciary were under his control. The legal seal of this otherwise unconstitutional law was sealed in 2011. The results of the two elections held in January 2014 and December 2011 have seen people win almost 100\% of Sheikh Sheikh Hasina's Awami Alliance. The whole world rejected them by saving India. She thought she was starting to exercise the tiger. Then, he was moved to take care of them he thought would harm them. Nevertheless, the fear of collapse that hid Sheikh Hasina, and made her a ruthless dictator, aimed to perpetuate, or walk for life. Notwithstanding, everything desists shortly or lately (R. Chowdhury, 2019).

\section{REFERENCES}

Alam, D. S. M. (2017). The Rise of an Orphan as "The Iron Lady of Asia" from the political instability after the gruesome assassination of - "Bangabandhu - The Father of the Nation. The International Journal of Social Sciences and Humanities Invention, 4(2), 3265-3276. https://doi.org/10.18535/ijsshi/v4i2.03

Ali, S. (2015). An Empirical Analysis of Population Growth on Economic Development: The Case Study of Bangladesh. International Journal of Economics, Finance and Management Sciences, 3(3), 252. https://doi.org/10.11648/j.ijefm.20150303.21

Anbarasan, E. (2012). Bangladesh Nationalist Party forms opposition alliance ' Loggerheads '. BBC News, Dhaka, 1-2. https://doi.org/https://www.bbc.com/news/world-asia-17755075

Antonio Savoia, M. N. A. (2019). Bangladesh is booming , but slide towards authoritarianism could burst the bubble. Theconversation.Com.

Chakma, B. (2015). Sheikh Hasina government's India policy: A three-level game? Journal of Asian Security and International Affairs, 2(1), 27-51.

Chowdhury, F. D. (2015). Problems of women's participation in Bangladesh politics. Round Table, 98(404), 555-567. https://doi.org/10.1080/00358530903151748

Hasan Mubashar, A. E. R. (2019). What went wrong with the BNP, Bangladesh's main opposition party? The BNP's defeat in last year's disputed election cannot be explained solely as a result of government repression. Al Jazeera, 1-6.

Hasina, N., \& Hasan, G. S. (2015a). Reconsideration of Local Government at Village Level : A Legal Reconsideration of Local Government Village Level: A Legal Study. Global Disclosure of Economics and Business, December 2015.

Hasina, N., \& Hasan, G. S. (2015b). Reconsideration of Local Government at Village Level: A Legal Study. Global Disclosure of Economics and Business, 4(2), 91-99. https://doi.org/10.18034/gdeb.v4i2.138

Huque, A. S., \& Ferdous, J. (2019). Bureaucratic and political leadership in Bangladesh: dynamics of administrative reform and the public interest. Asia Pacific Journal of Public Administration, 41(3), 169-180. https://doi.org/10.1080/23276665.2019.1658364

Islam, M. A., Ebrahimi, M., \& Yusoff, K. (2017). Major factors in the establishment of a caretaker government as an institution in Bangladesh. Man in India, 97(11), 23-36.

Islam, M. N., Islam, M. S., Islam, M. N., \& Islam, M. S. (2020). Islam, Islamism, and Democracy in Bangladesh. Islam and Democracy in South Asia, 215-260. https://doi.org/10.1007/978-3030-42909-6_8

Islam, S. S. (2016). Good governance and political culture: A case study of Bangladesh. Intellectual Discourse, 24(2), 31-57. 
Khazanah Sosial, Vol. 2 No. 3: 166-178

Political Ethics by Sheikh Hasina And Khaleda Zia's Government from 2009 to Present: A Research on Literature Review

Mohammad Eisa Ruhullah, Zuly Qodir

Jahan, R. (2014). Political Parties in Bangladesh. Centre for Policy Dialogue.

Jahan, R. (2018). Political Parties Movements, Elections and Democracy in Bangladesh.

Kabir, A., \& Parolin, B. (2012). Planning History Society Conference Planning and Development of Dhaka - a Story of 400 Years. 15th INTERNATIONAL PLANNING HI STORY SOCIETY CONFERENCE, 1(April), 1-20.

Karim, M. R. (2015). E-GOVERNMENT IN SERVICE DELIVERY AND CITIZEN' S SATISFACTION : A CASE STUDY ON PUBLIC SECTORS IN. International Journal of Managing Public Sector Information and Communication Technologies (IJMPICT), 6(2), 49-60.

Kaunain Rahman. (2019). Overview of Corruption and Anti- Corruption in Ghana. Transparency International (The Global Coalition Against Corruption), 2018, 1-18.

Khondker, H. H. (2017). Sheikh Hasina of Bangladesh: Politics, personality and policies. In Women presidents and prime ministers in post-transition democracies (pp. 221-237). Springer.

Lewis, D. (2017). Organising and Representing the Poor in a Clientelistic Democracy: the Decline of Radical NGOs in Bangladesh. Journal of Development Studies, 53(10), 1545-1567. https://doi.org/10.1080/00220388.2017.1279732

Mahmud, F. (2018). Is Bangladesh moving towards one-party state? Al Jazeera, 1-7.

Mohiuddin, Y. (2008). Sheikh Hasina and Khaleda Zia: Bangladesh's Military is Desperate to Bring Down these two Former Leaders-And it's Dragging the Whole Country down with them. International Journal, 63(2), 461-468.

Moniruzzaman M. (2016). Electoral Legitimacy, Preventive Representation, and Regularization of $\begin{array}{llll}\text { Authoritarian } & \text { Democracy. } & \text { IntechOpen, }\end{array}$ https://doi.org/http://dx.doi.org/10.5772/57353

Nasrin, F. (2013). Reforms in Local Government: Experiences from Bangladesh. Journal of Asia Pacific Studies, 3(1), 37-56.

Prothom Alo. (2019). 1209 people disappeared in last 10 yrs: BNP. Prothom Alo English Desk, 1011.

R. Chowdhury. (2019). Bangladesh : Sheikh Hasina 's Fear of Fall is The Issue. South Asia Journal, $1-6$.

Ranerup, A., \& Henriksen, H. Z. (2019). Value positions viewed through the lens of automated decision-making: The case of social services. Government Information Quarterly, October 2018, 101377. https://doi.org/10.1016/j.giq.2019.05.004

Salomon Heiner, Wake Caitlin, Jones Nicola, M. Q. (2019). Four priorities for Bangladesh 's new government in 2019. Overseas Development Institute.

Sarker, N. I., Bingxin, Y., Sultana, A., \& Prodhan, A. Z. M. S. (2017). Problems and challenges of public administration in Bangladesh : pathway to sustainable development. International Journal of Public Administration and Policy Research, 3(1), 16-25.

Shukla, A. (2018). BNP' s Narrowing Options in Bangladesh. Www.Icwa.In, 1-5.

TALIB A. YOUNISIQBAL M.D. MOSTAFA. (2018). ACCOUNTABILITY IN PUBLIC MANAGEMENT AND ADMINISTRATION IN BANGLADESH. In Routledge Revivals- Taylor \& Francis Group (Vol. 66).

timesnownews.com. (2018). Khaleda Zia, son directly involved in 2004 attack on Awami League rally : Bangladesh PM Sheikh Hasina. Www.Timesnownews.Com, 14-15.

UK Border Agency. (2011). BANGLADESH COUNTRY OF ORIGIN INFORMATION (COI) REPORT. In UK Border Agency (Issue December).

Zia, B. K. (2013). ZIA : The thankless role in saving democracy in Bangladesh. Washington Times, 17. 